\title{
Effect of straw mulching and herbicides on the weed density, dry matter accumulation of weeds and chlorophyll content in maize (Zea mays L.)
}

\author{
Ramandeep Kaur* and Charanjeet Kaur ${ }^{1}$ \\ Department of Agronomy, Punjab Agricultural University, Ludhiana (Punjab) India \\ (Email: ramandeepkaur201533@gmail.com)
}

\begin{abstract}
Field experiment was carried out during Kharif 2017 at Ludhiana and Gurdaspur to assess the weed density, DMA of weeds and chlorophyll content as influenced by straw mulching and herbicides in maize. Application of paddy straw mulch at 9.0 $\mathrm{t} \mathrm{ha}^{-1}$ effectively controlled the density and DMA of grasses, broadleaf and sedges and resulted in significantly more leaf chlorophyll content in maize as compared to paddy straw mulch at $6.25 \mathrm{t} \mathrm{ha}^{-1}$ and no mulching. Pre-emergence application of atrazine at $1.0 \mathrm{~kg} \mathrm{ha}^{-1}$ helped to manage density and DMA of grasses, broadleaf and sedges in comparison to atrazine at $0.8 \mathrm{~kg}$ $\mathrm{ha}^{-1}$ and unweeded check at 20 DAS. At 40 DAS of maize where maximum losses due to weeds occurred, the weeds were managed by post emergence application of tembotrione at 0.088 in combination with PSM $9.0 \mathrm{t} \mathrm{ha}^{-1}$ which reduced the density and DMA of grasses, broadleaf and sedges in comparison to atrazine at 0.8 and $1.0 \mathrm{~kg} \mathrm{ha}^{-1}$ and unweeded check, but were equally effective as compared to tembotrione at $0.110 \mathrm{~kg} \mathrm{ha}^{-1}$ and weed free treatment. The data showed that application of $9.0 \mathrm{t} \mathrm{ha}^{-1}$ mulch helped to reduce 20 per cent dose of atrazine and tembotrione for controlling weeds in maize.
\end{abstract}

Key Words : Atrazine, Maize, Straw mulching, Tembotrione, Weed density, Weed dry matter accumulation

View Point Article : Kaur, Ramandeep and Kaur, Charanjeet (2019). Effect of straw mulching and herbicides on the weed density, dry matter accumulation of weeds and chlorophyll content in maize (Zea mays L.). Internat. J. agric. Sci., 15 (1) : 107-114, DOI:10.15740/HAS/ IJAS/15.1/107-114. Copyright@ 2019: Hind Agri-Horticultural Society.

Article History : Received : 18.10.2018; Revised : 03.12.2018; Accepted : 08.12.2018

\footnotetext{
* Author for correspondence:

${ }^{1}$ Regional Research Station, Gurdaspur (Punjab) India (Email: virgocharan @ pau.edu)
} 